\title{
A CAREER IN LAW LIBRARIANSHIP: IN MEMORY OF GILLIAN SANDS
}

At the time of her tragic death, Gillian Sands had already established a successful career in law librarianship. She had trained at City University School of Information Science and worked in professional posts at two of the most prestigious legal research libraries in the UK. Gillian had also made friends at each stage of her career across all sectors of law librarianship and was highly valued by those with whom she had worked. She had played an important role in the social life of her workplace as well as being valued for her dedication, conscientiousness, and initiative. As a tribute to Gillian, this article traces her career in law librarianship and her various achievements. Ruth Bird, Librarian of the Bodleian Law Library, contributed to this article and helped me to write it. I also record my thanks to Gillian's friends and colleagues Alison, Caroline, Christine, Emily, Wendy, and others who wrote to me in February this year.

Gillian attended the University of Southampton between 1994 and 1997 reading for a BA in history. She won prizes for her performance in both her second and her final year history courses and was awarded a first class degree with honours.

Gillian had worked at Westminster Abbey bookshop during her gap year in 1993 and, during the vacations while studying for her degree, she worked as a steward at St Pauls Cathedral dealing with visitor enquiries, selling tickets and stewarding at services and on galleries. In retrospect one vacation period in the summer of 1996 stands out in terms of Gillian's choice of career; a period of six weeks voluntary work in the business library at the University of Westminster. Her responsibilities included journals management, inter-site reservations and helping with record enquiries and stock check. Clearly Gillian had identified librarianship as a possible career choice.

On completion of her degree in the following year Gillian obtained a one-year training post as Student Assistant in the library services of the University College London from August 1997. She had the opportunity to work in the Middlesex Hospital library and the History of Science/Mathematics library as well as in the periodicals department and at the main library issue desk. Gillian proved herself to be a thorough, painstaking and hardworking Student Assistant who related well to other colleagues. 'She is a modest person who made considerable achievements in her own quiet way.' Gillian also impressed by her performance in directly assisting readers through answering enquiries, a theme repeated in her appreciation of library and information work later in her career.

This gave Gillian a broad and varied introduction to academic librarianship. It also gave her valuable experience in handling enquiries effectively in a busy research environment and this was to remain an important element in the job satisfaction which Gillian gained from the profession. In this, as in all aspects of her professional life, Gillian identified closely on an emotional as well as practical level with library readers and was driven to improve services and, in doing so, was a major asset to the libraries for which she worked.

Gillian won a place on the MSc information science degree course at City University School of Information and attended the course in 1998 to 1999. She took the optional module in legal information as well as modules in social science and media 
information and in records management. Gillian's dissertation was on the Implications of Freedom of Information for Records Management in Government Departments. This was her own choice of subject and was topical both in terms of recent compliance issues but also in terms of a modern understanding of the scope of information studies. The research was empirical as well as book-based and involved conducting interviews with several Departmental Record Officers. The resulting dissertation was a substantial piece of work of high quality. A copy of the dissertation is now held in the library of City University and her supervisor for the project, Dr Tamara Eisenschitz described the work as thorough and creative.

One of the friends Gillian made at City University recalls that Gillian also took modules in information retrieval and communication skills and that the team project in information retrieval in which she participated involved creating a database, user manual and a thesaurus. The subject was the national lottery and Gillian singlehandedly created the thesaurus, not the easiest of subjects to organise.

Gillian made several friends during the course who remained close and shared the steps they made through their careers. These were joined by new friends she met her through her participation in BIALL, both contributing to its work for the profession and its social life. 'Conference discos will not be the same as we were always part of the same group on the dance floor, as one friend commented.

When Gillian applied for her first professional post in the Book Acquisitions Section of the Institute of Advanced Legal Studies library on 9 August 1999, a few days before her $25^{\text {th }}$ birthday, her application was characterised by a brief and wellorganised curriculum vitae. Her letter was well focussed and directed towards a career in law librarianship, clearly a deliberate choice of specialisation. She was excited by the challenge of working within a legal research environment; "my interest in working in a law library was very much spurred on by the option module in Legal Information which I chose as part of my course this year and which I thoroughly enjoyed."

Her references revealed Gillian to be extremely hardworking and academically able with good results throughout her information science course, performing particularly well in some of the more information technology intensive modules. She was clearly a very agreeable person to have in the Department at City University, as she later proved to be in the workplace at IALS, "She has excellent communication skills and behaves at all times in a dignified and highly professional manner. She has a genuine and passionate interest in information work and is determined to succeed in her chosen career." Her reference relating to her year at UCL Libraries was equally impressive. Needless to say, despite some understandable nervousness, Gillian impressed the interview panel of which I was a member.

Gillian started work at IALS on $13^{\text {th }}$ September 1999 , although typically she made time to join the annual round of induction of the new graduate trainees at the start of September at our invitation. Her post as Senior Library Assistant in the Book Acquisitions section involved a range of duties from clerical to academic liaison to aspects of collection development. She attended acquisitions meetings and immediately impressed by her preparation in identifying and investigating potential purchases, her stimulation of discussion, and her follow through. She was often the 
person to get the meeting on track and focus the discussion. She quickly took on the recording and production of the minutes of the meetings and all of us admired her for keeping us in order. Gillian also arranged book displays for the foyer of the Institute building and wrote a brief report on each for the Institute publication, Amicus Curiae and I had the pleasure of discussing possible themes for the displays with her.

Gillian also undertook public service duties on a rota basis. This is work under pressure on a huge range of queries from the very varied clientele of the library at the busy enquiry desk. Latterly this was to become an important element in her job at IALS. Later in $\mathbf{2 0 0 0}$ she also started to contribute regularly to the fee-based information and document delivery service run by IALS, answering enquiries from law firm librarians and others serving the practising profession. This service provides a link between IALS and those in the commercial sector and provided Gillian with another link to her friends in that sector.

Throughout her time at IALS, Gillian played a leading role in the social life, arranging events and collections, emailing the venue for celebratory drinks on a Friday evening or reminding us it was getting late to book for the Christmas meal. Her laughter with her head thrown back and her hand slightly raised as if to stifle it will stay with her friends as a fond memory.

When the opportunity arose in December 2000 to transfer to a post in the Reader Services Department, Gillian made known her interest and applied in the full competitive procedure. She moved to Reader Services on 15 January 2001 and it was noted that the interviewing panel were very impressed by her performance, as we all had been by her work at IALS. Gillian for her part noted that she had enjoyed working in the Book Acquisitions section at the Institute very much.

Gillian's new post was both demanding and very suitable to her talents. As part of a team dedicated to supporting and promoting use of the legal research facilities of the Institute library, she was particularly responsible for the day-to-day provision of services to LLM teachers and students, and for assistance in supporting the Institute's own staff and research students, as well as the general management of the reading rooms. The LLM is the University of London intercollegiate Master's Degree in Laws programme, the largest postgraduate taught course law programme in the world with almost 1500 students and 140 optional courses and teachers of international repute drawn from five law schools. The liaison role with teaching staff was demanding; the collection development role included the management of a budget for the extensive range of specialist material; in addition there was the management of a short loan collection of recommended reading for the LLM and provision of a readers' advisory service. Gillian responded to the challenge of this post enthusiastically and with characteristic thoroughness. She not only made a success of it but made something more of it and defined a new role within the library.

Gillian was promoted to the newly created post of Assistant Librarian in the Reader Services Department after an internal competition two years later in December 2002. This post combined her existing duties with a role deputising for the Reader Services Manager, a wider role in the day-to-day provision of reader services, and assistance with service development and administrative matters. There was a range of projects and initiatives from the prosaic to the cutting-edge, including a new system of signs 
for the library; at this time Gillian's parents and friends noticed her sudden interest in the design, siting and text of signs in every public building she visited.

Gillian was now responsible for two other members of staff. She was also responsible for the rota of all staff at the public service desks. Those lucky enough to work under her supervision benefited from an extremely sympathetic and caring manager while at the same time being drawn to live up to the very high standards which she set.

A major element of Gillian's duties was the development of the library role in training readers in the use of materials and research skills. This involved in-house training courses, particularly in the effective use of electronic resources, as well as creating training materials and guides for the Institute website. Gillian also played a leading role in giving introductory presentations to LLM students in their own University of London colleges, speaking to over 200 students. She herself readily admitted that this made her nervous but that did not deter her because it was the right thing to do and Gillian was always determined to do the right thing however difficult it was. In all this Gillian proved herself to be a driving force in improving services and information about services and being an advocate of readers' interests, proving her value both to them and to the institution as a result.

Gillian attended a wide range of training events during her career at IALS and her personnel file contains her reports on them. The reports are carefully worded and incisive and not only useful as management information on the quality and type of the training but also an extremely good read. At a hectic pace, she attended twelve courses in the first year including one on copyright a month after joining IALS and, a month later, the three-day Acquisitions School run by the National Acquisitions Group. In December, a course on presentation skills, "...the subject is an increasingly important one as communication skills are given more emphasis throughout the profession as a whole." Gillian attended various courses over the next eight months designed to assist in chartership of the Library Association: trends and developments in staff management, financial planning and management, collection management, a security workshop and also the BIALL introduction to legal reference materials, job interviewing skills, a visit to the Squire Law Library in the new Law Faculty building organised by the City Legal Information Group, and an introduction to international legal materials. Gillian herself organised several visits to other libraries including Lincoln's Inn Library and Queen Mary \& Westfield College Library. At a less hectic pace in the following year, she attended an introduction to web design, EU sources of legal information, managing change, moving into management, and virtual learning environments and libraries.

Gillian began her work towards chartership in November 1999, completing the approved route A training programme in November 2000. She quickly submitted her professional development report and became a chartered member of the Library Association in May 2001. Gillian attended the BIALL / University of Westminster Law for Law Librarians course from October 2000 to April 2001 consisting of two hours every Monday evening for six months. Gillian found the course very interesting and useful, "increasing my understanding of the sort of subjects which readers in the library may be studying and seeing their perspective." Of course, "It was also a very good opportunity for meeting others in law librarianship and swapping experiences 
and ideas". She again made lasting friends. By 2004, with her sights firmly set on user education, she applied for a place on a part-time course at Birkbeck College, University of London, leading to a certificate in teaching in lifelong learning, a course accredited by the Institute for Learning and Teaching in Higher Education.

In common with all new librarians at IALS, Gillian was encouraged to join the professional association and contribute to it. She joined BIALL soon after starting at IALS and quickly recognised the social and professional opportunities offered in good measure by BIALL. She had an early opportunity when she attended her first BIALL conference in June 2000 in Bristol after working at IALS for nine months. Gillian provided an admirable and balanced description of the conference sessions and concluded: "The informal networking opportunities which the conference offered were invaluable. Lunch and coffee breaks, the Sunday afternoon excursion and the evening events all allowed plenty of opportunities for swapping ideas, meeting new people, and discovering more about the varied aspects of law librarianship as well as for catching up with acquaintances! Overall I felt the conference was very worthwhile as well as thoroughly enjoyable." Gillian was to participate increasingly in BIALL and attend conferences including the $35^{\text {th }}$ annual conference in 2004 in Edinburgh, for which she showed an equal enthusiasm to that displayed in her report on the Bristol conference.

Gillian became an active member of BIALL. She joined the Editorial Board of Legal Information Management in November 2001 and became a valuable member and a good friend of the other members. She was appointed as Vice-Chair of the Editorial Board in Autumn 2004 after playing a leading role in the Board. The Chair recalls that, "she always brought something of value to a meeting with her calm manner and insightful comments". In autumn 2002 Gillian had taken over the preparation of the current awareness column of Legal Information Management (LIM), a task done for many years at IALS. She worked in partnership with June Tomlinson, later with Lesley Young and then for almost two years with Sam Weston-Smith until the winter 2004 issue when she handed over to Katherine Read in preparation for her move to Oxford. She also wrote articles for LIM, for example "Cat and class: what use are these skills to the new legal information professional" (LIM volume 2(2), 2002) drawing on the views and experience of nine professionals from various law libraries in the academic and commercial sectors. In a review in volume 3(1) of LIM she reported on the relatively new HeinOnline service which she had demonstrated to many students and to the Library Committee of IALS.

It was with great sadness that staff at IALS learned that Gillian was to leave the Institute library and not a little trepidation that we would have real difficulty in finding someone of her calibre who would carry out the demanding and varied duties so successfully. There was also a feeling of losing a good friend and an active agent provocateur who had facilitated important change in the library. However, we recognised that someone of Gillian's skill and determination would inevitably progress her career and needed to gain varied experience. It always remained our hope that she would one day return to an even more senior position at IALS library. She had considered a change of post for a little while and when the newly created post of Foreign and Comparative Law Librarian at the Bodleian Law Library in Oxford was advertised it was an opportunity too good to miss. When she discussed it within the library, despite their wish to retain her as long as possible, her 
colleagues supported this development of her career. It was clear to me that she was likely to succeed in her application. At her interview she impressed the panel with a wonderful and clear presentation showing a depth of understanding of issues in legal research which belied her years. The Bodleian Law Library staff were thrilled to welcome her as part of the team, bringing her extensive experience and expertise to help with the further development of their international and foreign law collections.

On 13 September I wrote an extensive reference for Gillian to support her application, describing her role as a driving force in moving us to large-scale delivery of electronic journals and remote access, her major role in user education, as well as her role in reference services, collection development, support of the Master's programme, and web initiatives, and her role in the social wellbeing of the IALS Library, concluding "I would be very sad to see Gillian leave IALS because she could undoubtedly become one of the most senior members of staff here if the opportunities arose. I can recommend her wholeheartedly as a major catch."

In August 2004, Gillian successfully applied for the newly created post of Foreign and Comparative Law Librarian at the Bodleian Law Library.

Gillian moved to Oxford and took up her post at the Bodleian Law Library in December 2004. In the brief time that she was there, her law library colleagues realised she would have become a great asset to the library. Her fascination with the subject was evident and her great enthusiasm for meeting and assisting readers was as strong as ever. She had already undertaken valuable work for the library with the production of reader guides and a survey of the US law collection.

Gillian Sands died on 31 January 2005 at the age of thirty.

At her leaving party on her last day at IALS, on Friday $3^{\text {rd }}$ December 2004, I had the privilege of wishing Gillian farewell on behalf of the Institute staff and speaking about her immensely valuable contribution to the library and to the life of the Institute where she had spent five very happy and productive years. We shall remember her as she was then, a talented and committed librarian who had made for herself a career in law librarianship. 